\title{
A LIST OF THE ORTHOPTERA OF ILLINOIS.-III.**
}

\author{
BY JEROME MCNEILL, FAYETTEVILIE, ARK.
}

Acrididae (Oedipodini, Truxalini.) 46. Arphia sulphurea Fab. This is a common species throughout the state. In the northern part of the state there is but one brood a year and the individuals pass the winter as larvae or pupae, being found in exactly the same localities as Chortophaga viridifasciata De Geer and Hitpiscus tuberculatus Pal. de Beauv. They become full fledged as early as the I 4 th of May and disappear about the first of July.

*47. Arphia xanthoptera Burm. This species is said by Thomas to inhabit Illinois, but I have seen no specimens that could be referred with certainty to this species unless indeeed $A$. carinata Scudd. is a synonym. I have been inclined to this opinion but Saussure still continues to separate them and it is probable that he has been able to compare carinata Scudd. with Burmeister's type.

48. Arphia carinata Scudd. This is a very common species throughout the state, formerly thought to be a variety of sulphurea Fab., but it seems to be quite distinct and the two species are now placed in different divisions of the genus. In practice they may be distinguished by the facial costa which

\footnotetext{
* In the first two parts of this paper, in almost every case where I have accredited specimens to the Museum of the University of Illinois, I should have said the Museum of the Illinois State Laboratory of Natural History.
}

is acuminate towards the vertex in sulphurea, while in carinata Scudd. the sides of the facial costa are nearly parallel from the median ocellus to the vertex. The carina of the pronotum of the latter is very high and strongly arched while in the former it is but little elevated and nearly straight. The earliest appearance of this species in northern Illinois is the 2oth of August.

49. Arphia tenebrosa Scudd. Mr. Thomas says this species is occasionally seen in the extreme northwestern part of the state.

50. Chortophaga viridifasciata De Geer. Common throughout the state, though never very abundant. The larvae and pupae winter in the same situations with Arphia sulphurea and complete their transformations only a few days sooner than the last mentioned species. This species is the first of the order to reach maturity in the spring and the note of the male is the beginning of the grasshopper chorus which continues for six months or more. It is a very variable species, but all of the varieties may be referred to two forms, the green and the brown, which is a seasonal form apparently and therefore worthy of a name according to the rules of systematic zoölogy. It should therefore be called Chortophaga viridifasciata infuscata Harris. This form as has frequently been remarked is the com- 
mon one in the early spring and while green males are very rare at this season green females are common; later the green form predominates and the brown form is the one of exceptional occurrence, but the males are less uncommon than the females. In the northern part of the state there is but one brood that hatched from eggs in the late summer and matured the following spring, so that the form infuscata is the common one always. In Moline I have captured full grown specimens as early as the twenty-second of April and as late as the seventh of July.

5I. Encoptolophus sordidus Burmeister. Common throughout the State but more abundant northward. While the males of many species and the females of some species occasionally fly with a crackling noise, the males of this species seem not to be able to fly at all without making this noise. This is a fortunate circumstance for the collector since the dark color and the short and exceedingly quick flight of the male make it very difficult to follow. I captured specimens from August twenty-first to the thirtieth of October.

*52. Cammula pellucida Scudd. This species undoubtedly occurs in the northern part of the state although I have never seen a specimen taken within its borders. I have specimens from Wisconsin and Mr. Thomas includes the species in his List of the Orthoptera of Illinois on the authority of Mr. Scudder.

53. Hippiscus tuberculatus Pal. de Beauv. This a rather common species in the early spring. Larvae and pupae pass the winter under the shelter of leaves and grass and mature very early in the spring, about the first of May. It shows a decided preference for certain localities, being found year after year in the same field or on the same hillside. From these favorite haunts it never seems to wander far although apparently well able to fly across the state. There are two places each a few rods square on Rock Island where 1 have never failed to find them summer or winter and these are the only places where they are to be found on the Island, which is three-fourths of a mile wide and three miles long.

54. Hippiscus rugosus Scudd. This species is also rather common at Moline and probably throughout the state. The red and the yellow winged forms are found in about equal numbers in Rock Island Co. except on the "Sand Hill" where they are quite common and all apparently yellow-winged. I have taken them on Rock Island as early as the 2 oth of August. A specimen in the Illinois state laboratory of natural history bears the date of Aug. 14, taken at Pekin.

55. Hippiscus phoenicopterus Burm. This is the species formerly known as H. discoideus Serv. while the species that used to bear the name phoenicopterus is now known to be H.tuberculatus Pal. de Beauv. I have taken a a single species at Moline. It is probably a rare species throughout the state. Taken the $5^{\text {th }}$ of September.

*56. Xanthippus neglectus Thos. Thomas says he captured it in the 
southern part of the state but thinks it is rarely found there. I do not know of its occurrence elsewhere.

57. Dissosteira carolina Linn. Abundant everywhere along roadsides and railroads especially. Taken as early as the $25^{\text {th }}$ of June.

*58. Spharagemon aequale Say. It is not certain that this species occurs in the state although Thomas says it is found "throughout the greater part of the state." It is in no collections that I have seen while the species next named is abundant wherever I have collected in Illinois or Iowa or Indiana; but as its occurrence here is not improbable I have not excluded it from the list.

59. Spharagemon bolli Scudd. Common on dry hillsides. It makes its appearance as early as the 2 rst of June. This is the only species with which I am acquainted, except Dissosteira carolina Linn., that remains stationary a few feet above the ground and in some manner produces a dry rustling note. I have known this species to go through the performance in but one instance although it was repeated several times by different individuals. As four out of the five individuals that I captured on the spot were males, the thought suggested itself that it might be a part of the courtship of the species.

6o. Spharagemon collare Scudd. This species occurs rarely on the tops of high sandy hills, in Rock Island Co. and doubtless throughout the state as I have found it as far south as Pine Bluff, Ark., where individuals were found abundant along the sandy shore of the
Arkansas River. They are abundant however on the "Sand Hill." They have been taken at Moline as early as the 28 th of August.

6r. Psinidia fenestralis Serv. This has been found, so far as I know, in but a single locality in the state, the sand hill at Moline Bridge. It is abundant here on the bare sand. Its crimson wings make it conspicuous but when on the ground it is so small and colored so nearly like the sand that it is not easy to see it and its flights are so short and quick that it is not very easy to capture. Aug. 28th is the earliest recorded date of its capture.

*62. Mestobregma cincta Thos. Said by Thomas to occur sparingly in southern Illinois.

63. (?) Philobostroma parva Scudd. I think I am not mistaken in referring to this species a considerable number of individuals found on the sand hill, Sept. 2, and at Cordova Sept. 28. They are very variable in size and color but as the lateral foveolae are always very distinct they are easily distinguished from Philobostroma quadrimaculata Thos.

*64. Trimerotropis maritima Harr. Said by Thomas to occur in the northern part of the state.

65. Circotettix verruculatus Kirby. The collection of the State laboratory of natural history contains two specimens, one from Henry, Ill., and the other from Birds Point, Mo.

66. Chloëaltis viridis Scudder. Seems to be common throughout the state, but it is never abundant. Specimens of both the brown and green varie- 
ties will be found in any locality, but so far as my experience goes the green specimens far outnumber the brown everywhere and at all seasons. It is a grass loving species as indeed are the group Truxalini generally, being in this respect strongly contrasted with the Oedipodini, which very generally prefer barren hillsides or other localities characterized by somewhat scanty vegetation. The short wings as in allied species are quite variable. I have one in my cabinet with elytra and wings quite as long as the abdomen. Specimens have been taken at Moline as early as the ninth of July, and as late as the fifteenth of October.

67. Chloealtis conspersa Scudder. Probably found throughout the state, though never abundant and perhaps not everywhere common. The females are very likely to be confused with the brown females of the preceding species from which they may always easily be separated by the slight median carina of the vertex. The wings and elytra as in the preceding species are quite variable, one specimen in my collection having elytra which extend one fourth their length beyond the tip of the abdomen. The species is noted for the exhibition of a habit not possessed by any other member of the family so far as is now known. This peculiarity is its habit of depositing its eggs in holes bored in slightly decayed wood. This fact was first reported by Mr. S. I. Smith in his List of the Orthoptera of Maine. It has since been corroborated by the observations of Mr. C. A. Hart of Champaign.* This species makes its

\footnotetext{
*See also Scudder. Rep. Geol. N. Hampshire v. I, 37 I-372.
}

appearance in spring even earlier than C. viridis; indeed I know of but one other, Pezotettix viridulus Walsh, that is developed earlier from eggs hatched in the spring. It has been found in Moline as early as the twenty-first of June and as late as the twenty-fourth of September.

68. Stenobothrus curtipennis Harris. Quite common throughout the state and generally more abundant than either of the two preceding species. It has a decided preference for thick blue grass growing in partially shaded situations. Like its allies it can scarcely be said to either fly or jump, but it suffers little or nothing in lacking these accomplishments as its astonishing facility as a tumbler and contortionist generally discourage all but the most determined efforts for its capture. It appears almost as early in the spring as the preceding species, its first recorded appearance at Moline being the twenty-third of June, and its latest appearance the twentyfourth of September.

69. Stenobothrus maculipennis Scudd. This very variable species is common in a few localities. It occurs on the "Sand Hill" several times referred to and described in this paper. It is found too on the barren or sandy tops of the highest hills along the bluffs of the Mississippi and Rock Rivers. It is full-fledged about the first of August. 70. Syrbula admirabilis Uhler. Widely distributed but rare or uncommon. Thomas described the brown form of the male and did not know of the existence of the green form. I have raised from pupae several males which 
show the usual green color and markings of the females. The earliest appearance at Moline is August 22.

*7. Mermiria bivittata Serville. Very rare if it occurs at all in the state. Mr. Thomas thinks he has seen one specimen taken within this limit. It has been taken at Omaha, Nebraska, by Mr. Lawrence Bruner so that its occurrence here is very probable.

72. Truxalis brevicornis Linn. This is a southern species but it extends as as far north as Urbana, Illinois, where I am told by Mr. C. A. Hart it has been frequently taken at the electric light, as many as seven or eight having been taken in one evening, August sixteenth-

Lestes eurinus Say.-This species appears never to have been taken since Harris's day, who obtained his specimens on the borders of ponds in Milton, Mass., in 1826 . The only notices which have been published since the description by Say, in 1839 , have been based solely on his text. The accompanying description is from the type (a $\delta$ ) in the Harris collection of the Boston Society of Natural History. It is a true Lestes.

Greenish blue above, yellowish beneath. Head bronze blue above, yellow beneath; apex of clypeus, labrum, sides of mandibles, and front of face very pale greenish blue, glistening. Thorax bright blue above with violaceous reflections and with dorsal and lateral sutures yellowish brown; sides of thorax blue, the side of mesothorax with a biserrate lemon yellow spot occupying lower posterior third, that of metathorax yellow with an oblique triangular fuscous stripe; base of all the legs, and under surface of femora (especially of posterior pair) yellow; upper surface of femora, lower surface of tibiae and tarsi brownish green; upper surface of tibiae fuscous; wings subhyaline or very slightly flavescent, pterostigma black;
I 888 . The frequent occurrence of a rare species at the electric light is more remarkable since it is of very rare occurrence for the commonest species of Acrididae to visit a light.

73. Arcyptera lineata Scudder. A very rare form in the northern part of the state. I have taken a few specimens on the Iowa side of the Mississippi opposite Watertown. This is pretty certainly the species from the northern part of the state, which Thomas says he saw for too short a time to certainly identify. In his list it is given as Stetheophyma (Arcyptera) gracilis? Scudd. The single specimen in my collection was captured August 9 .

abdominal segments I-5 above blue, 6-10 blackish green; beneath very pale fuscous, more dusky posteriorly, their apices blackish; superior appendages forcipated, beneath bidentate interiorly; the first tooth at the extremity of the basal fourth sharply pointed, directed posteriorly; the second, just beyond the middle, depressed, laminate, denticulate, directed toward that of the opposite appendage (inferior appendages lost); thirteen postcubital cross nervules on right, fifteen on left fore wing.

Length (inc. forceps) $46 \mathrm{~mm}$.; alar expanse; $59 \mathrm{~mm}$.; length of pterostigma, 2.5 $\mathrm{mm}$.

Samuel H. Scudder.

HeMidiptera HAECKELII.-Entomologists who would derive the Diptera from the Hemiptera, if any such exist, will be delighted to find in the last number of the Jenaische zeitschrift für naturwissenschaft (bd. 25, heft. I $\& 2,1890$, p. I3-I5) a description of what purports to be a "zwischenform" connecting these two widely separated orders. Dr. N. Léon figures and gives a brief description of an insect taken by Prof. Ernst Haeckel in Ceylon together with species of 

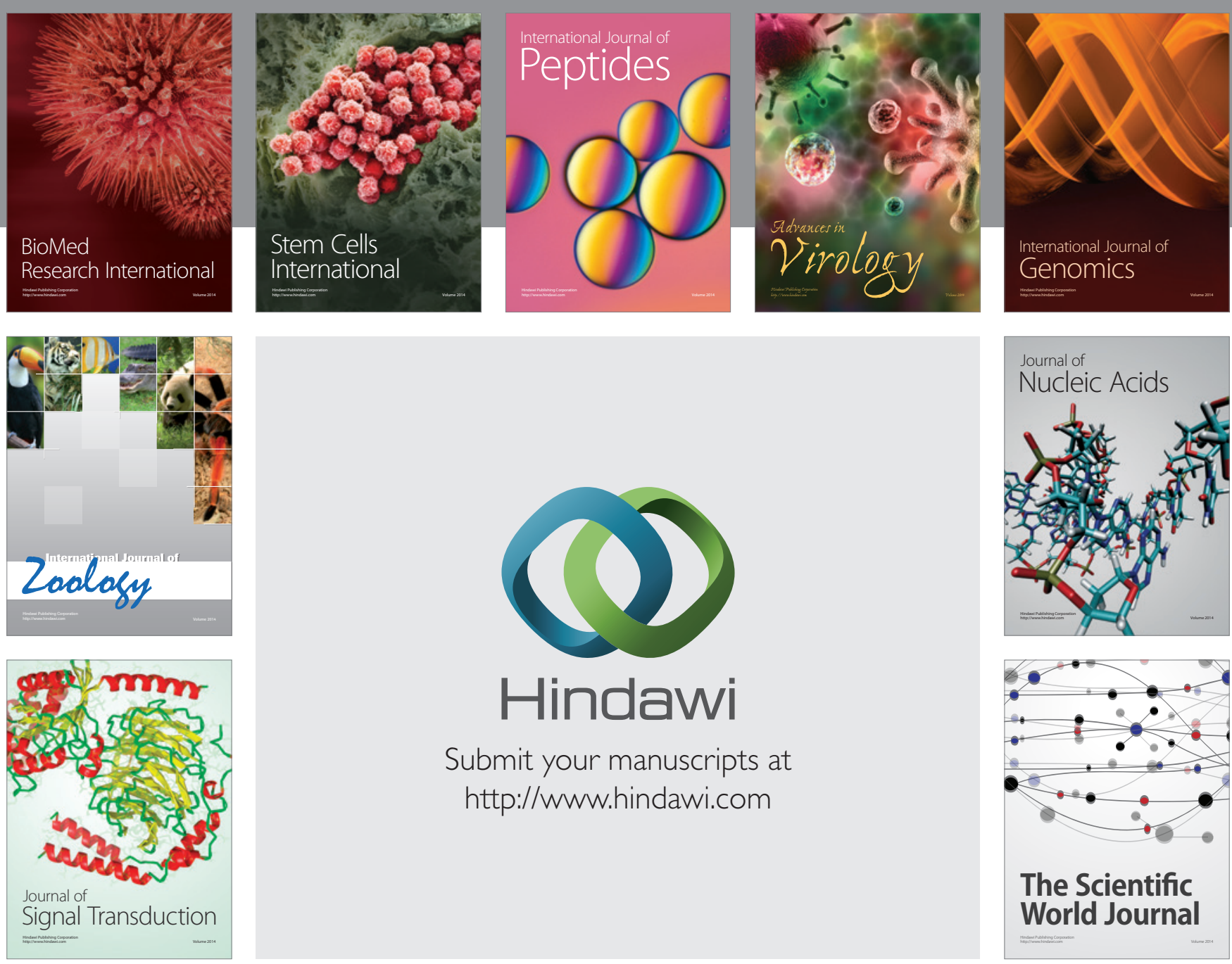

Submit your manuscripts at

http://www.hindawi.com
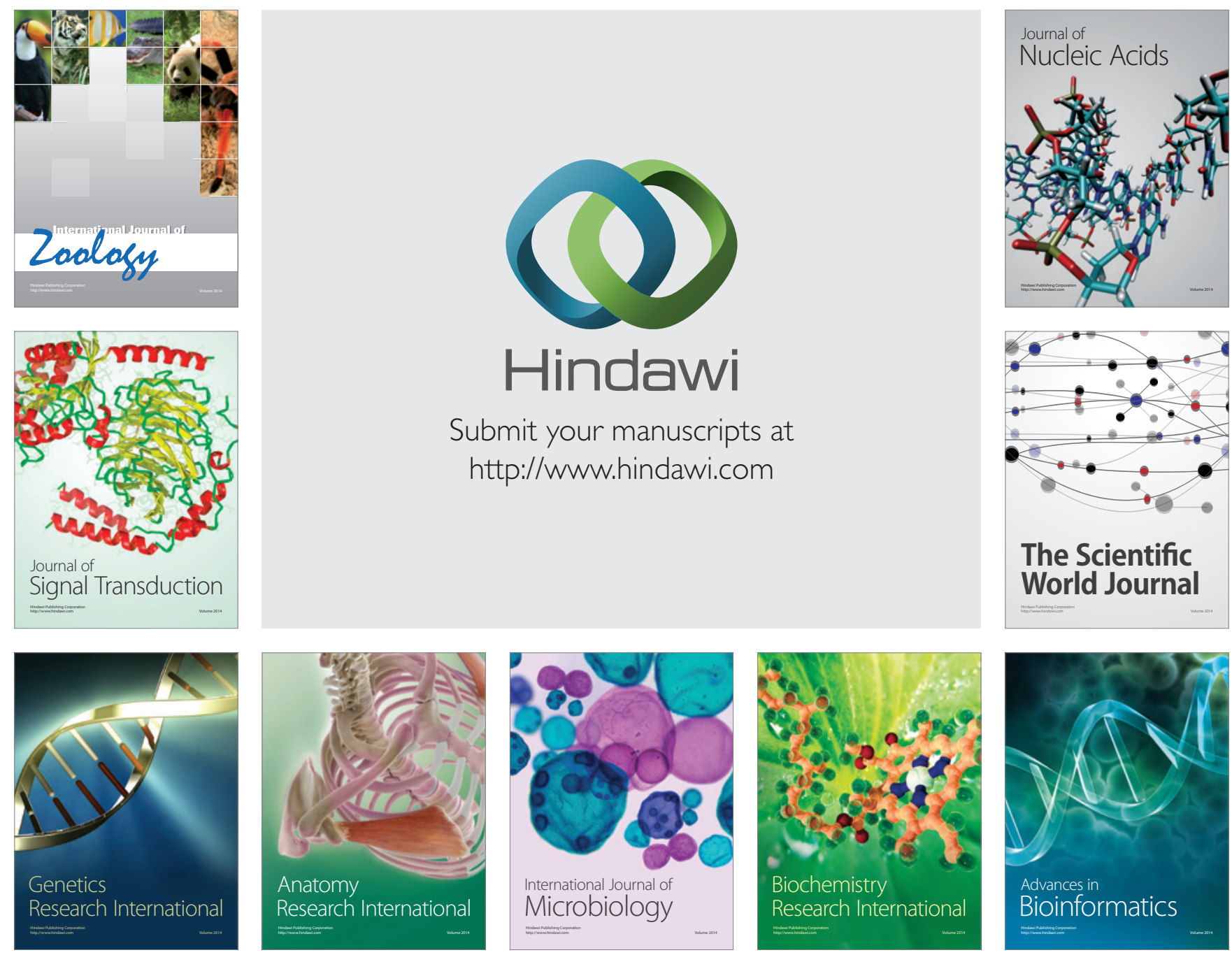

The Scientific World Journal
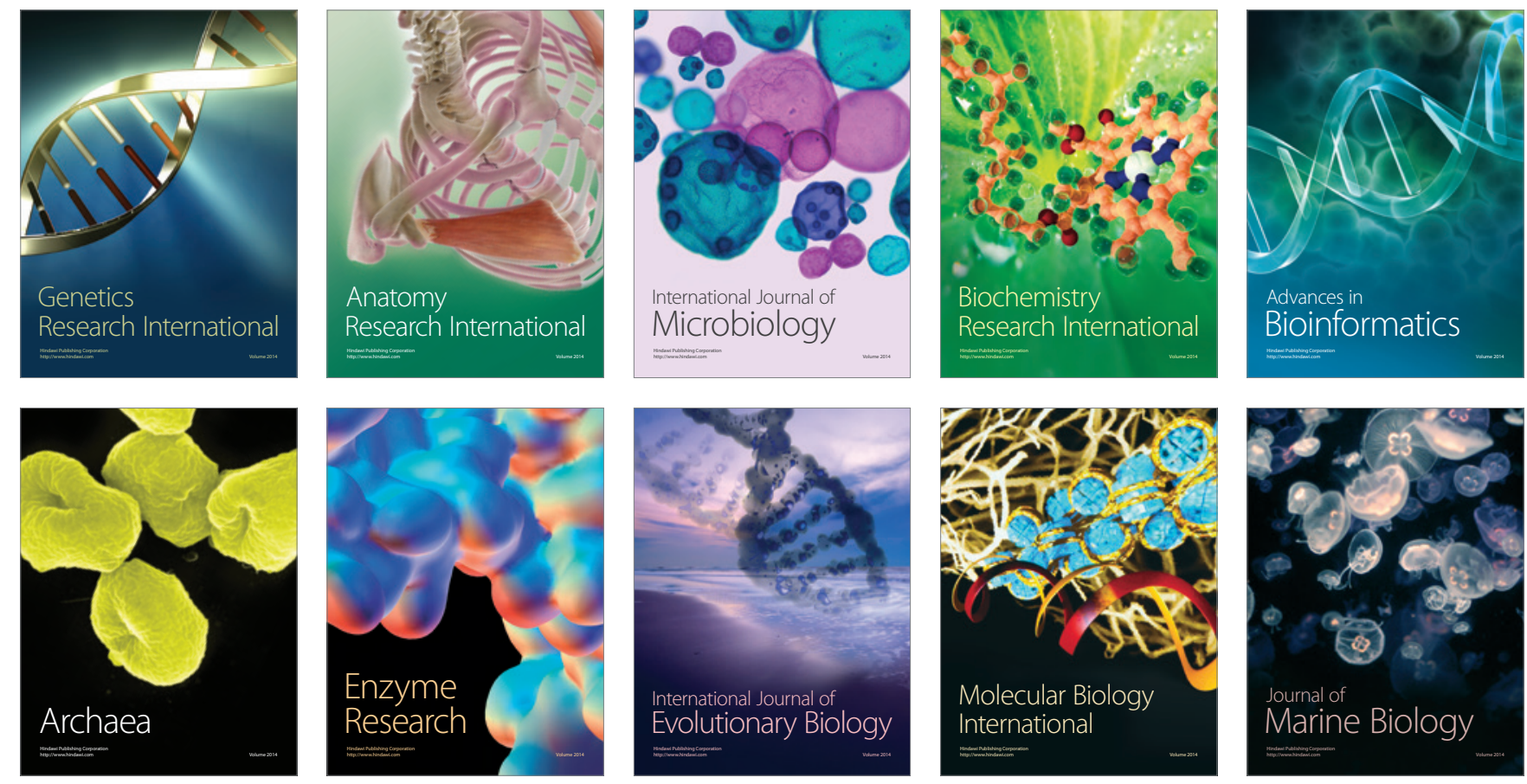